of the central part of the Loch Awe Syncline with their high structural position. The hypothesis is that these rocks were not deeply covered during their metamorphism, and accordingly were never raised to any very high temperature.

\title{
OOREFSFONDFNOH.
}

\section{CRITICAL TEMPERATURES AND CRITICAL CONTROVERSY.}

SIR,-Referring to Dr. Johnston-Lavis' letter, I am sorry if I have failed to do him justice. I have a list of eighty of his papers to 1890 , none, however, bearing on critical temperatures. If he will send me references to any subsequent ones bearing on the action of superheated water I shall be obliged.

And now I must throw myself on your Editorial leniency and that of your readers.

On the day $I$ received the proofs of the article which appears this month I suffered a serious nervous collapse, and am under strict orders to spare myself in every way, and this just at a moment when the Survey Memoir of Dartmoor makes it incumbent on me to review nearly thirty years of observation of that district; and Mr. Jukes-Browne's papers on "The Making of Torbay" and on "The 'Torquay Limestones" do the same for about forty years' reflections on the raised beaches and general geology of that district! In addition to this there is a good deal that wants saying about Kent's Cavern.

I am very sorry to have broached subjects in your columns which I cannot for the moment now defend, in critical controversy, but I will try to meet any objections, or yield to them, if possible later on. If not in this Magazine, then somewhere else.

SOUTHWOOD, TorquaY.

A. R. Hent.

March 7, 1913.

\section{PREHISTORIC BEADS.}

SIR,-As a supplement to my letter in the GroL. MAG. for March, p. 138, and your reply thereto, pp. 139-43, I send you the following quotation from Sir Charles Lyell's Antiquity of Man (4th edition, p. 165). He writes as follows: "In the gravel-pits of St. Acheul, and
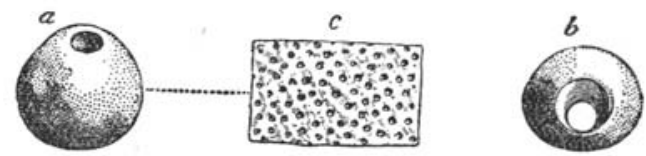

$a, b$, Porosphara globularis, Phillips, copied from Lyell's Antiquity of Man, 4th ed., p. 165, fig. 22, 1873; c, part of same magnified.

in some others near Amiens, small round bodies, having a tubular cavity in the centre, occur. They are well known as fossils of the White Chalk. Dr. Rigollot suggested that they might have been strung 